\title{
Long-term Trends in Fertility of Soils under Continuous Cultivation and Cereal Cropping in Southern Queensland. V* Rate of Loss of Total Nitrogen from the Soil Profile and Changes in Carbon : Nitrogen Ratios
}

\author{
R. C. Dalal and R. J. Mayer \\ Queensland Wheat Research Institute, \\ Department of Primary Industries, Toowoomba, Q1d 4350.
}

\begin{abstract}
The kinetics of total $\mathrm{N}$ loss from the top $(0-0.1 \mathrm{~m}$ ) and the subsoil (up to $1.2 \mathrm{~m}$ depth) of six southern Queensland soils after different periods (0-70 years) of cultivation and cereal cropping, were studied. The equation: $N_{\mathrm{t}}=N_{\mathrm{e}}+\left(N_{\mathrm{o}}-N_{\mathrm{e}}\right) \exp (-k t)$, where $N_{\mathrm{o}}, N_{\mathrm{e}}$ and $N_{\mathrm{t}}$ are total $\mathrm{N}$ concentrations initially, at equilibrium and at time $t$, respectively, and $k$ is the rate of loss of total $\mathrm{N}$ from soil, described total $\mathrm{N}$ loss from only three soils. For the $0-0.1 \mathrm{~m}$ depth, the $k_{\mathrm{w}}$ values (based on weight of total $\mathrm{N} /$ volume of soil) were $0.061,0.115$ and 0.275 year $^{-1}$, respectively for Waco (black earth; initially grassland), Langlands-Logie (grey, brown and red clays; brigalow) and Cecilvale soil (grey, brown and red clays; poplar box). The $k_{\mathrm{w}}$ values decreased to less than half at $0-0.6 \mathrm{~m}$ depths of those at $0-0.1 \mathrm{~m}$ depth.

In the other three soils, Billa Billa (grey, brown and red clays; belah), Thallon (grey, brown and red clays; coolibah) and Riverview (red earth; silver-leaved ironbark), total $\mathrm{N}$ declined linearly over the 20-25 years of cultivation period studied.

Average annual rates of $\mathrm{N}$ loss from the profiles of the six soils, respectively, were $31 \cdot 3,67 \cdot 1,34 \cdot 5$, $50 \cdot 8,35 \cdot 8$ and $32 \cdot 0 \mathrm{~kg} \mathrm{~N}^{-1}$ year $^{-1}$, from Waco, Langlands-Logie, Cecilvale, Billa Billa, Thallon and Riverview soils. Except for Langlands-Logie, these losses could be accounted for by crop $\mathrm{N}$ removal. In the Langlands-Logie soil, besides $\mathrm{N}$ removal by crop $\left(51 \mathrm{~kg} \mathrm{~N}^{-1}\right.$ year $^{-1}, 1982-1984$ period), leaching of $\mathrm{N}$ below the root-zone appeared to be the likely factor for $\mathrm{N}$ loss.

$\mathrm{C}: \mathrm{N}$ ratios generally increased with depth in the five clay soils but decreased with depth in the red earth (Riverview). Cultivation had no significant effect on the C:N ratios of Cecilvale, Thallon and Riverview soils, but it caused a decrease in Langlands-Logie soil (up to $0.6 \mathrm{~m}$ depth) and an increase in Waco soil (up to $1.2 \mathrm{~m}$ depth). It was inferred, therefore, that in the latter, remaining soil $\mathrm{N}$ was likely to mineralise more slowly with increasing period of cultivation, resulting in a fertility loss which may be greater than that shown by the decrease in total $\mathrm{N}$.
\end{abstract}

\section{Introduction}

Cultivation of a soil previously supporting native vegetation or pasture generally leads to a reduction in its organic $\mathrm{C}$ and $\mathrm{N}$ concentrations (Clarke and Marshall 1947; Haas et al. 1957). Dalal and Mayer (1986a) observed declines of 19-45\% in organic $\mathrm{C}$ in six major soils of the southern Queensland cereal belt for cultivation periods ranging from 20 to 70 years. The rate of soil organic $\mathrm{C}$ loss varied from 0.065 to 1.224 year $^{-1}$ (Dalal and Mayer $1986 b$ ).

The estimates of soil total $\mathrm{N}$ losses even from Vertisols are varied. Martin and Cox (1956) measured $0.8 \%$ annual decrease in soil $\mathrm{N}$ from the $0.15 \mathrm{~m}$ layer, whereas Waring and Teakle (1960) estimated that about $3 \%$ of the total soil $\mathrm{N}$ was removed by wheat crops annually. Russell (1981) observed even higher $\mathrm{N}$ losses (about 5\% per year) from an initially highly fertile Vertisol cropped to sorghum continuously for 10 years. 
Generally rates of organic matter loss from cultivated soils can be inferred from either organic $\mathrm{C}$ or $\mathrm{N}$ losses. However, it is only after long periods of cultivation that losses of soil $N$ are proportional to the losses of organic C (Jenkinson 1966). Thus, along with the rates of organic $C$ losses studied earlier (Dalal and Mayer $1986 \mathrm{~b}$ ), the rates of total $\mathrm{N}$ losses from six major soil series of the southern Queensland cereal belt should provide a better understanding of organic matter dynamics in these soils. We report in this paper the kinetics of total $\mathrm{N}$ in six soils, the estimates of annual total $\mathrm{N}$ loss from the soil profile $(0-1 \cdot 2 \mathrm{~m}$ depth) and $\mathrm{N}$ removal by crops, and trends in $\mathrm{C}: \mathrm{N}$ ratios of organic matter in these soils subjected to 20-70 years of continuous cultivation for cereal cropping. Soil properties that are associated with total $\mathrm{N}$ and $\mathrm{C}: \mathrm{N}$ ratios are also reported.

\section{Materials and Methods}

The study area, soil management and cultural practices, and soil sampling and analytical techniques are described by Dalal and Mayer $(1986 a, 1986 \mathrm{~b})$. Mean values of clay content, and total $\mathrm{N}$ concentrations, $\mathrm{C}: \mathrm{N}$ ratio, and $\mathrm{pH}$ of the soils from virgin sites $(0-0 \cdot 1 \mathrm{~m}$ depth) are given in Table 1 .

Table 1. Mean values of soil $\mathrm{pH}$, clay content, total $\mathrm{N}$, and $\mathrm{C}: \mathrm{N}$ ratio of the top layer $(0-0 \cdot 1 \mathrm{~m})$ from virgin sites

\begin{tabular}{|c|c|c|c|c|c|}
\hline $\begin{array}{l}\text { Soil series } \\
\text { (No. of sites) }\end{array}$ & Great Soil Group & $\begin{array}{c}\mathrm{pH} \\
(1: 5 \\
\left.\mathrm{H}_{2} \mathrm{O}\right)\end{array}$ & $\begin{array}{l}\text { Clay } \\
(\%)\end{array}$ & $\begin{array}{c}\text { Total N } \\
(\% 0)\end{array}$ & $\begin{array}{l}\mathrm{C}: \mathrm{N} \\
\text { ratio }\end{array}$ \\
\hline Waco clay (5) & Black earth ${ }^{A}$ & $8 \cdot 1$ & 74 & $0 \cdot 144$ & $11 \cdot 3$ \\
\hline $\begin{array}{l}\text { Langlands-Logie } \\
\text { clay (6) }\end{array}$ & $\begin{array}{l}\text { Grey, brown and red } \\
\text { clays }\left(\text { Brigalow) }^{\mathrm{B}}\right.\end{array}$ & $7 \cdot 4$ & 49 & $0 \cdot 203$ & $10 \cdot 9$ \\
\hline Cecilvale clay (7) & $\begin{array}{l}\text { Grey, brown and red } \\
\text { clays (Poplar box) }\end{array}$ & $7 \cdot 4$ & 40 & $0 \cdot 133$ & $13 \cdot 0$ \\
\hline $\begin{array}{l}\text { Billa Billa loamy } \\
\text { clay (7) }\end{array}$ & $\begin{array}{l}\text { Grey, brown and red } \\
\text { clays }(\text { Belah) }\end{array}$ & $7 \cdot 4$ & 34 & $0 \cdot 139$ & $10 \cdot 6$ \\
\hline Thallon clay (6) & $\begin{array}{l}\text { Grey, brown and red } \\
\text { clays (Coolibah) }{ }^{\mathrm{B}}\end{array}$ & $7 \cdot 2$ & 59 & $0 \cdot 065$ & $11 \cdot 8$ \\
\hline $\begin{array}{l}\text { Riverview sandy } \\
\text { loam (5) }\end{array}$ & Red earth ${ }^{C}$ & $6 \cdot 5$ & 19 & $0 \cdot 084$ & $15 \cdot 2$ \\
\hline
\end{tabular}

A Typic Pellusterts. ${ }^{B}$ Typic Chromusterts: ${ }^{C}$ Rhodic Paleustalfs.

Total $\mathrm{N}$ concentration of the air-dried and ground $(<0.25 \mathrm{~mm})$ soil samples were determined by the Kjeldahl method, adapted to include nitrite and nitrate (Dalal et al. 1984). Appropriate adjustments were made to correct for differences in sampling depths as a result of bulk density changes with cultivation (Dalal and Mayer 1986b). This was done by regarding each virgin site as a 'standard' for its set of corresponding cultivated sites. The values of bulk density measured at field capacity at each depth were used to obtain for each cultivated site a sequence of 'equivalent' depth intervals at the virgin site. Then, from the total $\mathrm{N}$-depth distribution relationships at each cultivated site, total $\mathrm{N}$ concentrations were estimated for each equivalent depth interval.

Total $\mathrm{N}$ removed by the crops from the cultivated soils was estimated from the $\mathrm{N}$ yield-period of cultivation relationship for 1983 cereal crops (Dalal and Mayer 1986a) and total number of crops grown, and then annual $\mathrm{N}$ removal was calculated from the number of years the soil had been cultivated. Estimates of annual crop $\mathrm{N}$ removal were also made from the mean $\mathrm{N}$ yields of the cereal crops for the 1982-84 period in order to minimise seasonal effects on crop $\mathrm{N}$ yields. Nitrogen contained in the stubble was considered totally lost if stubble was burnt. The sampling and analytical procedures for obtaining crop $\mathrm{N}$ yields were described previously (Dalal and Mayer 1986a). 


\section{Results}

\section{Total $N$ Concentration and $C: N$ Ratios of Virgin Soils}

Most of the total $\mathrm{N}$ in the top soil $(0-0.1 \mathrm{~m}$ depth) is organic, since mineral $\mathrm{N}$ accounted for less than $0.5 \%$ of total $\mathrm{N}$ and fixed ammonium- $\mathrm{N}$ in these Vertisols and red earths is generally low (Black and Waring 1972). Total $\mathrm{N}$ concentration of the virgin soils $(0-0.1 \mathrm{~m})$ varied from $0.065 \%$ in Thallon clay to $0.203 \%$ in Langlands-Logie clay (Table 1). Except for Langlands-Logie soil supporting brigalow (Acacia harpophylla), total $\mathrm{N}$ was significantly correlated $\left(r=0.90^{*}\right.$ ) over 83-101 years with mean annual rainfall (over 83-101 years), although less closely so than the latter with organic C (Dalal and Mayer 1986b). This was reflected in differences in $\mathrm{C}: \mathrm{N}$ ratios among the soils (Table 1).

The soil properties significantly $(n=36, P<0.05)$ associated with total $\mathrm{N}$, besides organic $\mathrm{C}(r=0.95)$ and organic $\mathrm{P}(r=0.77)$, were total $\mathrm{K}(r=-0.48)$, total $\mathrm{S}(r=0 \cdot 50), \mathrm{pH}(r=0 \cdot 39)$, electrical conductivity $(r=0 \cdot 73)$, urease activity $(r=0.66)$ and oxalate-extractable Fe $(r=0.44)$. More than $86 \%$ of the variation in total $\mathrm{N}$, however, was accounted for by the combined linear effects of total $\mathrm{P}$, total $\mathrm{K}$, electrical conductivity and urease activity of these soils.

The total amounts of $\mathrm{N}$ in virgin profiles of Waco, Langlands-Logie, Cecilvale, Billa Billa, Thallon and Riverview were $7700 \pm 390,8690 \pm 450,6740 \pm 190$, $7100 \pm 380,5400 \pm 510$ and $5460 \pm 450 \mathrm{~kg} \mathrm{~N} \mathrm{ha}{ }^{-1} 1 \cdot 2 \mathrm{~m}^{-1}$, respectively, and generally were positively correlated with the mean annual rainfall.

The C:N ratio of the virgin soils was significantly correlated $(P<0.01)$ with electrical conductivity $(r=-0.62)$, dithionite-Fe $(r=0.66)$ and bulk density $(r=$ $0 \cdot 82$ ) and these together accounted for $85 \%$ of the variation of $\mathrm{C}: \mathrm{N}$ ratio of these virgin soils $(n=36)$.

The C:N ratio generally increased with depth in five Vertisols (Waco, from 11 $(0-0 \cdot 1 \mathrm{~m})$ to $15(0 \cdot 9-1 \cdot 2 \mathrm{~m})$; Langlands-Logie, from 11 to 16 ; Cecilvale, from 13 to 17 ; Billa Billa, from 11 to 13 ; Thallon, from 12 to 16 ), but decreased in Riverview (red earth) from $15(0-0 \cdot 1 \mathrm{~m})$ to $12(0 \cdot 9-1 \cdot 2 \mathrm{~m})$.

\section{Rate of Loss of Total $N$ from the Top Soil Layer (0-0.1 m Depth)}

The changes in total $\mathrm{N}$ concentration with period of cultivation were described by the exponential equation:

$$
N_{\mathrm{t}}=N_{\mathrm{e}}+\left(N_{\mathrm{o}}-N_{\mathrm{e}}\right) \exp (-k t),
$$

where $N_{\mathrm{o}}, N_{\mathrm{e}}$ and $N_{\mathrm{t}}$ are total $\mathrm{N}$ concentrations initially $(t=0)$, at equilibrium $(\mathrm{t} \rightarrow \infty)$, and after cultivation period $t$ (years), respectively, and $k$ is the rate constant $\left(\right.$ year $\left.^{-1}\right)$.

Where $k$ was not significant (standard errors estimated according to Draper and Smith 1966) at $P<0.05$, a linear regression equation (2) was used to describe the total $\mathrm{N}$-period of cultivation relationship,

$$
N_{\mathrm{t}}=N_{\mathrm{o}}-a_{1} t
$$

where $a_{1}$ is the regression coefficient, and $N_{\mathrm{t}}, N_{\mathrm{o}}$ and $t$ have the same meanings as in equation 1 .

Total $\mathrm{N}$ concentrations in relation to the period of cultivation are shown in Fig. 1. Changes in total $\mathbf{N}$ concentrations were described by equation 1 , in Waco, 
Langlands-Logie and Cecilvale soils (Fig. 1a, Table 2 ) and by equation $2\left(N_{\mathrm{o}}\right.$ and $a_{1}, P<0.05$ ) in Billa Billa, Thallon and Riverview soils (Fig. 1b, Table 3).

The values of $N_{\mathrm{o}}, N_{\mathrm{e}}, k_{\mathrm{c}}$ and half-life, $t_{1 / 2}\left(t_{1 / 2}=\ln 2 / k\right)$, estimated on a concentration basis (w/w, g N $100 \mathrm{~g}^{-1}$ soil) for six soils are given in Table 2 .

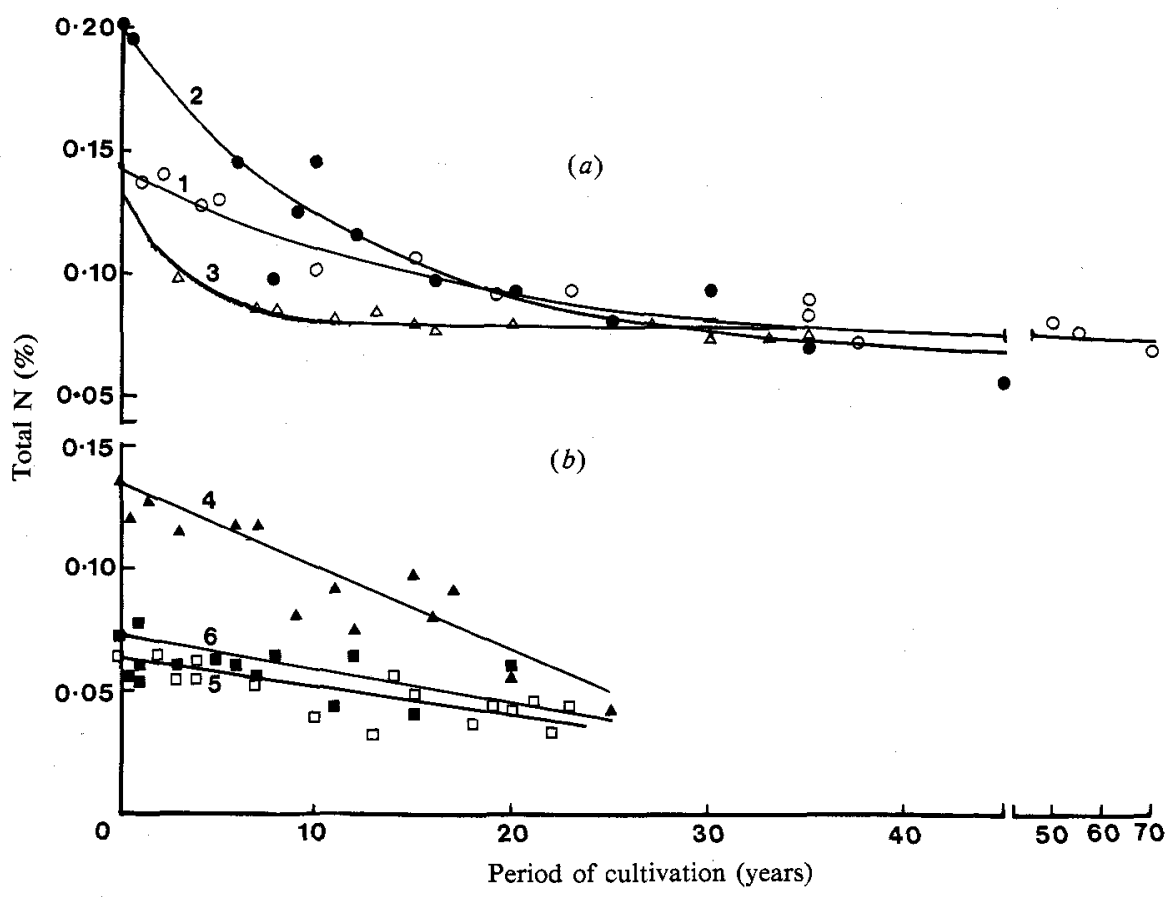

Fig. 1. Total $\mathrm{N}$ concentrations in relation to the period of cultivation. Curves are drawn according to $(a)$ equation 1 , and $(b)$ equation $2.1, \bigcirc$ Waco;,$\bigcirc$ Langlands-Logie; $3, \triangle$ Cecilvale; 4, $\wedge$ Billa Billa; 5, $\square$ Thallon; 6, $\square$ Riverview.

Table 2. Initial values $\left(N_{\mathrm{e}}\right)$, equilibrium values $\left(N_{\mathrm{e}}\right)$, overall rate of loss $\left(k_{\mathrm{e}}\right)$ and half-life of loss $\left(t_{1 / 2}\right)$ of total $N$ from the top layer $(0-0 \cdot 1 \mathrm{~m}$ ) of six soils (on weight of total $N /$ weight of soil basis)

\begin{tabular}{lcccccc}
\hline Soil series (No. of sites) & $\begin{array}{c}\text { Period of } \\
\text { cultivation } \\
\text { (years) }\end{array}$ & $\begin{array}{c}N_{\mathrm{o}} \\
\text { mean } \pm \text { s.e. } \\
(\% \mathrm{~N})\end{array}$ & $\begin{array}{c}N_{\mathrm{e}} \\
\text { mean } \pm \text { s.e. } \\
(\% \mathrm{~N})\end{array}$ & $\begin{array}{c}k_{\mathrm{c}} \\
\text { mean } \pm \text { s.e. } \\
\text { (year-1) }\end{array}$ & $\begin{array}{c}t_{1 / 2} \\
\text { mean } \pm \text { s.e. } \\
\text { (year) }\end{array}$ & $R^{2}$ \\
\hline Waco clay (21) & $1-70$ & $0.144 \pm 0.003$ & $0.072 \pm 0.005$ & $0.059 \pm 0.011$ & $11.8 \pm 2.3$ & 0.95 \\
Langlands-Logie (18) & $0.5-45$ & $0.201 \pm 0.007$ & $0.068 \pm 0.015$ & $0.086 \pm 0.026$ & $8 \cdot 1 \pm 2.4$ & 0.89 \\
Cecilvale (19) & $3-35$ & $0.133 \pm 0.001$ & $0.078 \pm 0.001$ & $0.274 \pm 0.043$ & $2 \cdot 5 \pm 0.4$ & 0.98 \\
Billa Billa (21) & $0.5-25$ & $0.135 \pm 0.005$ & $\mathrm{NS}$ & $\mathrm{NS}$ & - & 0.80 \\
Thallon (22) & $2-23$ & $0.066 \pm 0.003$ & $0.039 \pm 0.007$ & $\mathrm{NS}$ & - & 0.68 \\
Riverview (18) & $0.5-20$ & $0.083 \pm 0.005$ & $0.057 \pm 0.003$ & $\mathrm{NS}$ & - & 0.60 \\
\hline
\end{tabular}

NS, not significant; standard errors (s.e.) were estimated by Gauss-Newton method (Draper and Smith 1966).

Similar to the rates of organic C loss (Dalal and Mayer 1986b), the $k_{\mathrm{c}}$ value of total $\mathrm{N}$ loss was higher for Cecilvale than for Waco and Langlands-Logie soils. The $k_{\mathrm{c}}$ values for the other three soils were not significant (Table 2), that is, total $\mathrm{N}$ decreased linearly (Table 3 ) rather than exponentially with period of cultivation. 
The $N_{\mathrm{e}}$ values ( $n=5$, Table 2 ) were closely correlated with mean annual rainfall $\left(r=0.99^{* *}\right)$ and also with mean annual temperature $(r=0.94 *)$ (Fig. 2), possibly reflecting the amount of dry matter produced and organic residues returned to the soil.

Table 3. Initial values $\left(N_{0}\right)$ and regression coefficients $\left(a_{1}\right)$ of total $N$ from the top layer $(0-0 \cdot 1 \mathrm{~m})$ of three soils (on weight of total $\mathrm{N} /$ weight of soil basis)

\begin{tabular}{lccc}
\hline Soil series & $\begin{array}{c}N_{0} \\
\text { mean } \pm \text { s.e. } \\
(\% \mathrm{~N})\end{array}$ & $\begin{array}{c}a_{1}^{\mathrm{A}} \\
\text { mean } \pm \text { s.e. } \\
\left(\% \mathrm{~N} \times 10^{2} \text { lost year }\right.\end{array}$ & $\left.R^{2}\right)$ \\
\hline Billa Billa & $0.134 \pm 0.004$ & $0.34 \pm 0.04$ & 0.80 \\
Thallon & $0.063 \pm 0.002$ & $0.11 \pm 0.02$ & 0.63 \\
Riverview & $0.073 \pm 0.004$ & $0.15 \pm 0.05$ & 0.31 \\
\hline
\end{tabular}

A Average annual rates of loss on the basis of weight of total $\mathrm{N} /$ volume of soil (0-0.1 $\mathrm{m}$ depth) were $28 \cdot 6,10.4$ and $16.7 \mathrm{~kg} \mathrm{~N}^{-1}$ year $^{-1}$, respectively. Both $N_{0}$ and $a_{1}$ are significant at $P<0.05$.

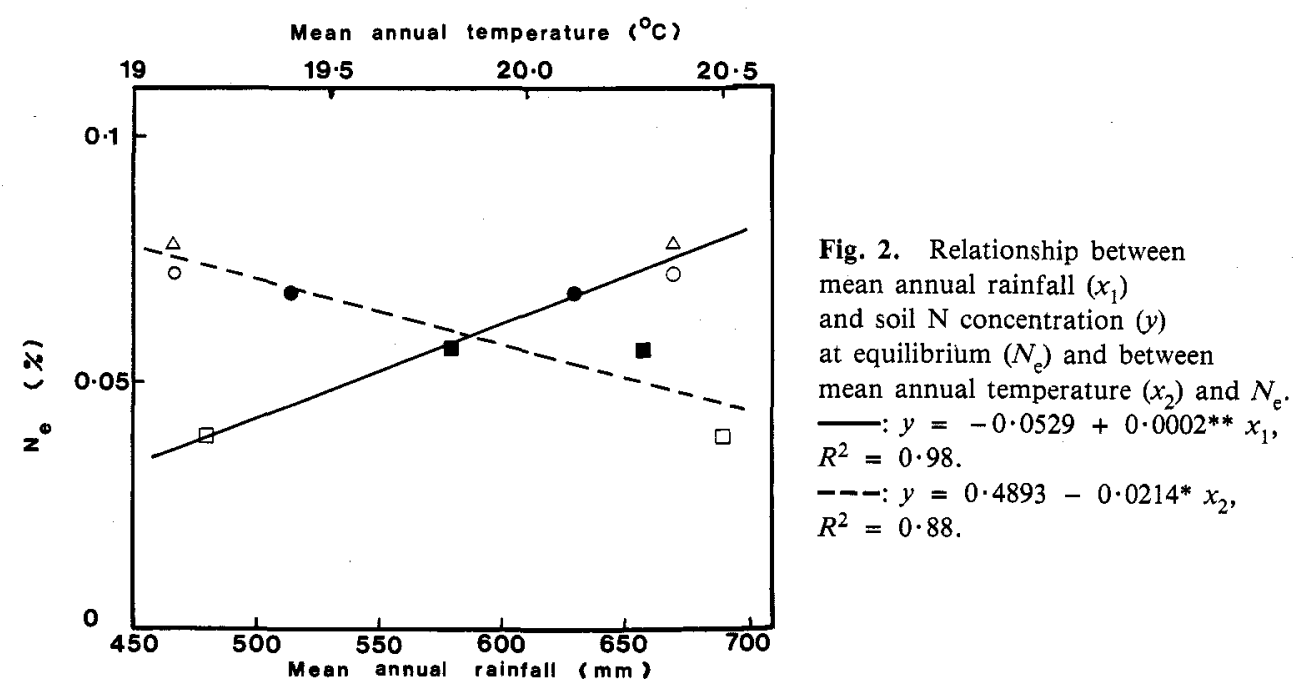

In Billa Billa, Thallon and Riverview soils, total $\mathrm{N}$ decreased linearly at the rate of $0.34 \times 10^{-2}, 0.11 \times 10^{-2}$ and $0.15 \times 10^{-2} \% \mathrm{~N}$ year -1 , respectively (Table 3).

So that changes in total $\mathrm{N}$ at different depths in the profile can be compared between soils, the kinetic parameters (equation 1) were also calculated on the basis of weight of total N/volume of soil for equivalent depths of adjacent virgin soil. The $k$ values calculated on weight/volume ( $k_{\mathrm{w}}$, Table 3 ) were generally higher (Langlands-Logie) than or similar (Waco and Cecilvale) to those calculated on a concentration basis $\left(k_{\mathrm{c}}\right.$, Table 2$)$. Linear decreases in soil $\mathrm{N}$ in Billa Billa, Thallon and Riverview soils, over the observed period of cultivation, showed respective $N$ loss rates of $28 \cdot 6,10: 4$ and $16 \cdot 7 \mathrm{~kg} \mathrm{ha}^{-1}$ year $^{-1}$ from the $0-0 \cdot 1 \mathrm{~m}$ layer (Table 3). 


\section{Losses of Total $N$ from the Subsoil Layers}

Significant rates of loss of total $\mathrm{N}$, which were satisfactorily described by equation (1), occurred up to $0.6 \mathrm{~m}$ depth in Waco and Cecilvale soils and up to $0.9 \mathrm{~m}$ depth in Langlands-Logie soils (Table 4). However, the $k_{\mathrm{w}}$ values decreased and the $t_{1 / 2}$ values increased with depth, so that $\mathrm{N}$ losses from the $0-0.6 \mathrm{~m}$ layer were only half as rapid as those from the top $(0-0.1 \mathrm{~m})$ layer.

Table 4. Initial values $\left(N_{0}\right)$, equilibrium values $\left(N_{\mathrm{e}}\right)$, overall rate of loss $\left(k_{\mathrm{w}}\right)$ and half-life of loss $\left(t_{1 / 2}\right)$ of total $\mathbf{N}$ from different depths in three soils (weight of total $\mathrm{N} /$ volume of soil basis)

\begin{tabular}{|c|c|c|c|c|c|c|}
\hline Soil series & $\begin{array}{l}\text { Soil depth } \\
\text { (m) }\end{array}$ & $\begin{array}{c}N_{o} \\
\text { mean } \pm \text { s.e. } \\
\left(\mathrm{kg} \mathrm{ha}^{-1}\right)\end{array}$ & $\begin{array}{c}N_{\mathrm{e}} \\
\text { mean } \pm \text { s.e. } \\
\left(\mathrm{kg} \mathrm{ha}^{-1}\right)\end{array}$ & $\begin{array}{c}k_{\mathrm{w}} \\
\text { mean } \pm \text { s.e. } \\
\left(\text { year }^{-1}\right)\end{array}$ & $\begin{array}{c}t_{1 / 2} \\
\text { mean } \pm \text { s.e. } \\
\text { (year) }\end{array}$ & $R^{2}$ \\
\hline \multirow[t]{4}{*}{ Waco clay } & $0-0 \cdot 1$ & $1220 \pm 20$ & $610 \pm 30$ & $0.061 \pm 0.010$ & $11 \cdot 4 \pm 1 \cdot 7$ & 0.96 \\
\hline & $0-0 \cdot 2$ & $2170 \pm 40$ & $1170 \pm 90$ & $0.048 \pm 0.012$ & $14 \cdot 4 \pm 3 \cdot 5$ & 0.93 \\
\hline & $0-0 \cdot 3$ & $2910 \pm 50$ & $1710 \pm 130$ & $0.045 \pm 0.013$ & $15 \cdot 4 \pm 4 \cdot 3$ & 0.91 \\
\hline & $0-0.6$ & $4860 \pm 70$ & $3080 \pm 400$ & $0.027 \pm 0.011$ & $25 \cdot 7 \pm 10 \cdot 9$ & 0.89 \\
\hline \multirow[t]{5}{*}{ Langlands-Logie } & $0-0 \cdot 1$ & $1990 \pm 80$ & $850 \pm 120$ & $0.115 \pm 0.038$ & $6 \cdot 0 \pm 1 \cdot 9$ & 0.86 \\
\hline & $0-0 \cdot 2$ & $3250 \pm 100$ & $1670 \pm 180$ & $0.101 \pm 0.033$ & $6 \cdot 9 \pm 2 \cdot 2$ & 0.87 \\
\hline & $0-0 \cdot 3$ & $4280 \pm 110$ & $2370 \pm 200$ & $0.097 \pm 0.028$ & $7 \cdot 1 \pm 2 \cdot 1$ & 0.89 \\
\hline & $0-0 \cdot 6$ & $6230 \pm 120$ & $3670 \pm 350$ & $0.063 \pm 0.019$ & $11 \cdot 0 \pm 3 \cdot 4$ & 0.90 \\
\hline & $0-0 \cdot 9$ & $7630 \pm 130$ & $4270 \pm 890$ & $0.036 \pm 0.017$ & $19 \cdot 1 \pm 8 \cdot 8$ & 0.89 \\
\hline \multirow[t]{4}{*}{ Cecilvale } & $0-0 \cdot 1$ & $1350 \pm 20$ & $800 \pm 20$ & $0.275 \pm 0.041$ & $2 \cdot 5 \pm 0 \cdot 4$ & 0.98 \\
\hline & $0-0 \cdot 2$ & $2230 \pm 20$ & $1580 \pm 30$ & $0 \cdot 174 \pm 0.033$ & $4 \cdot 3 \pm 0 \cdot 8$ & 0.96 \\
\hline & $0-0 \cdot 3$ & $3040 \pm 40$ & $2270 \pm 60$ & $0.141 \pm 0.038$ & $4 \cdot 9 \pm 1 \cdot 3$ & 0.92 \\
\hline & $0-0 \cdot 6$ & $5020 \pm 80$ & $3860 \pm 220$ & $0.078 \pm 0.035$ & $8 \cdot 9 \pm 4 \cdot 1$ & 0.82 \\
\hline
\end{tabular}

Table 5. Annual rate of loss of $\mathbf{N}$ from profiles of six soils

\begin{tabular}{lccc}
\hline Soils & $\begin{array}{c}\text { Soil depth } \\
(\mathrm{m})\end{array}$ & $\begin{array}{c}\text { Rate of loss } \\
\left(\mathrm{kg} \mathrm{N} \mathrm{ha}^{-1} \mathrm{yr}^{-1}\right)\end{array}$ & $R^{2}$ \\
\hline Waco & $0-1 \cdot 2$ & $31 \cdot 3 \pm 3 \cdot 0$ & $0 \cdot 85$ \\
Langlands-Logie & $0-0 \cdot 9$ & $67 \cdot 1 \pm 6 \cdot 9$ & $0 \cdot 89$ \\
Cecilvale & $0-0 \cdot 9$ & $34 \cdot 5 \pm 5 \cdot 5$ & $0 \cdot 70$ \\
Billa Billa & $0-0 \cdot 3$ & $50 \cdot 8 \pm 7 \cdot 6$ & $0 \cdot 70$ \\
Thallon & $0-0 \cdot 6$ & $35 \cdot 8 \pm 8 \cdot 6$ & $0 \cdot 46$ \\
Riverview & $0-0 \cdot 3$ & $32 \cdot 0 \pm 11 \cdot 0$ & $0 \cdot 32$ \\
\hline
\end{tabular}

\footnotetext{
A Calculated from $N_{\mathrm{t}}=N_{\mathrm{o}}-a_{1} t$, where $N_{\mathrm{o}}$ and $N_{\mathrm{t}}$ are cumulative soil $\mathrm{N}\left(\mathrm{kg} \mathrm{ha}^{-1}\right)$ for the depths shown, initially $(t=0)$ and after $t$ years of cultivation, respectively, and $a_{1}$ is rate of loss $\left(\mathrm{kg} \mathrm{N} \mathrm{N}^{-1}\right.$ year $\left.{ }^{-1}\right)$. Both $N_{0}$ and $a_{1}$ are significant at $P<0.05$.
}

\section{Annual Rates of $N$ Loss from the Soil Profiles}

The profile depths where significant losses of total $\mathrm{N}$ were measured ranged from 1.2 to $0.3 \mathrm{~m}$ in Waco, Langlands-Logie, Cecilvale, Billa Billa, Thallon and Riverview (Table 5). Amount of $\mathrm{N}$ lost annually, expressed as a linear function of period of cultivation $(P<0.05)$, from the six soil series was similar in Waco, Cecilvale, Thallon and Riverview soils (31-36 $\left.\mathrm{kg} \mathrm{N}^{-1} \mathrm{year}^{-1}\right)$, but much greater from Billa Billa $\left(51 \mathrm{~kg} \mathrm{~N}\right.$ ha ${ }^{-1}$ year $\left.{ }^{-1}\right)$ and Langlands-Logie $\left(67 \mathrm{~kg} \mathrm{~N} \mathrm{ha}^{-1}\right.$ 
year $^{-1}$ ) soils (Table 5). However, as a proportion of the total amount of $\mathrm{N}$ to similar depths in virgin soils, annual $\mathrm{N}$ loss was least $(0 \cdot 4 \%)$ in Waco soil and most $(1 \cdot 7 \%)$ in Billa Billa and Riverview soils. Generally, the higher the clay content the less was the annual proportional rate of soil $\mathrm{N}$ loss.

\section{Estimates of Annual $N$ Removal by Crops}

The estimates of mean annual $\mathrm{N}$ removal by crops, calculated from the $\mathrm{N}$ yield-period of cultivation relationship obtained in 1983, varied from $38 \mathrm{~kg} \mathrm{~N}^{-1}$ (Riverview) to $89 \mathrm{~kg} \mathrm{~N} \mathrm{ha}^{-1}$ (Billa Billa); average annual removals from these soils during 1982-84 period were 35 and $67 \mathrm{~kg} \mathrm{~N} \mathrm{ha}^{-1}$ year $^{-1}$ respectively (Table 6).

Table 6. Estimates of $\mathbf{N}$ removal by crop

\begin{tabular}{lcc}
\hline Soils series & $\begin{array}{c}\text { Mean N removed by crop }\left(\mathrm{kg} \mathrm{ha}^{-1} \text { year }\right. \\
\text { From } 1983 \text { harvest }\end{array}$ & $\begin{array}{c}\text { From } \\
\text { 1982-84 harvest }\end{array}$ \\
\hline Waco & $48 \pm 15$ & $59 \pm 21$ \\
Langlands-Logie & $57 \pm 6$ & $51 \pm 13$ \\
Cecilvale & $41 \pm 6$ & $45 \pm 16$ \\
Billa Billa & $89 \pm 30$ & $66 \pm 25^{\mathrm{B}}$ \\
Thallon & $45 \pm 19$ & $42 \pm 20^{\mathrm{B}}$ \\
Riverview & $38 \pm 16$ & $35 \pm 17^{\mathrm{B}}$ \\
\hline
\end{tabular}

A $\mathrm{N}$ removed in grain only when stubble retained and both in grain and straw when stubble burnt (Dalal and Mayer 1986a).

${ }^{B}$ From 1983 and 1984 harvests only.

Except for the Langlands-Logie soil, estimated $\mathrm{N}$ removals by crops were similar to or exceeded the mean annual rates of $\mathrm{N}$ loss from soil (Table 5). Estimated $\mathrm{N}$ removal by crops may have differed in earlier years due to differences in seasonal conditions, cultivars and management.

\section{Changes in C:N Ratio upon Cultivation}

Changes in $C: N$ ratio $(0-0 \cdot 1 \mathrm{~m})$ with period of cultivation were described by the following equation in Waco, Langlands-Logie and Billa Billa soils (Fig. 3):

$$
(\mathrm{C}: \mathrm{N})_{t}=(\mathrm{C}: \mathrm{N})_{0}+\alpha t+\beta t^{2},
$$

where $(C: N)_{0}$ and $(C: N)_{t}$ are the $C: N$ ratios initially and after $t$ years of cultivation, and $\alpha$ and $\beta$ are regression coefficients.

In Waco soil, the $\mathrm{C}: \mathrm{N}$ ratio increased linearly with period of cultivation at the rate of approximately $4 \%$ year $^{-1}$, suggesting an increase in relatively resistant fractions of organic matter with increasing period of cultivation.

In Langlands-Logie and Billa Billa soils, however, the relationship was curvilinear. In the former, $\mathrm{C}: \mathrm{N}$ ratio first increased $(\leqslant 12$ years) and then decreased, whereas in the latter it decreased initially ( $\leqslant 10$ years) and then increased with period of cultivation (Fig. 3). In a soil where various fractions of organic matter differ significantly in their decomposition rates (Dalal and Mayer 1986c, $1986 d$ ), the interpretation of changes in C: $N$ ratio of the whole soil with period of cultivation is difficult. 
The C:N ratios of the soil profiles of Waco generally increased with depth as well as with the period of cultivation (Table 7). The $\mathrm{C}: \mathrm{N}$ ratios in Langlands-Logie soil were significantly reduced upon cultivation at the rate of approximately $4 \%$ year $^{-1}$. The $\mathrm{C}: \mathrm{N}$ ratio-period of cultivation relationship was still curvilinear at $0 \cdot 1-0 \cdot 2 \mathrm{~m}$ depth in Billa Billa soil, although at greater depths the $\mathrm{C}: \mathrm{N}$ ratio was not significantly affected by cultivation.

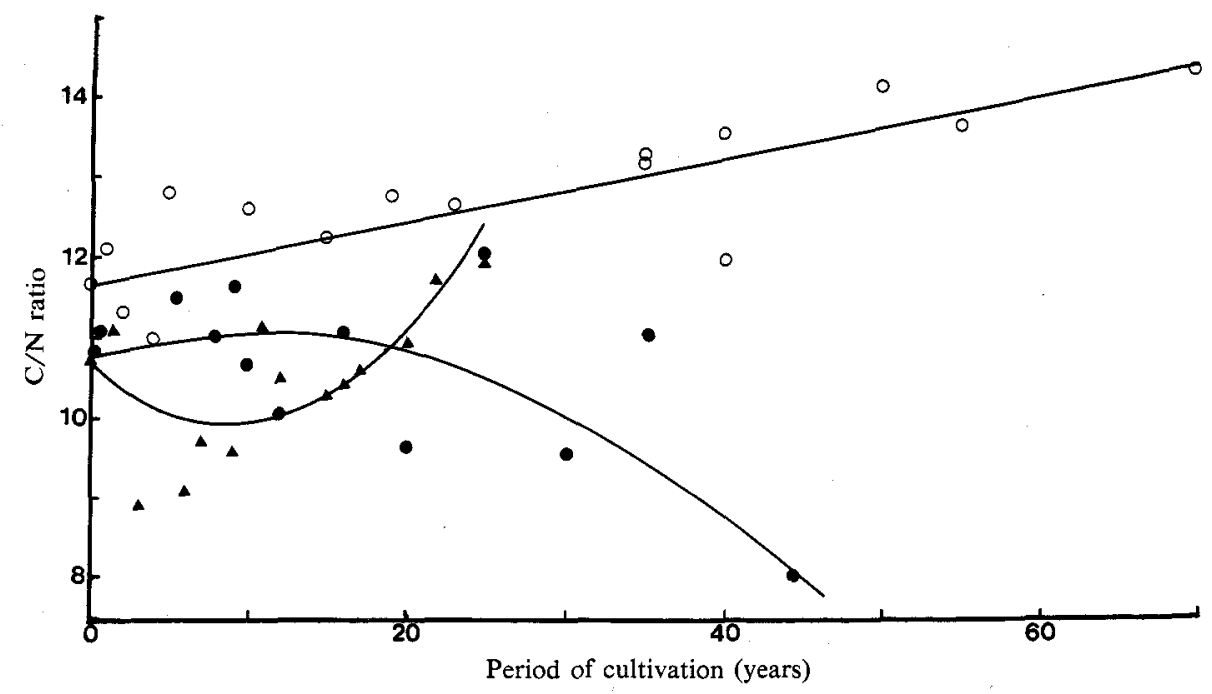

Fig. 3. Changes in $\mathrm{C}: \mathrm{N}$ ratio $(y)$ with period of cultivation $(x)$ in three soils $(0-0 \cdot 1 \mathrm{~m}$ depth). Waco: $y=11.68+0.046^{* *} x, R^{2}=0.74$.

Langlands-Logie: $y=10.80+0.063 * x-0.0028 * x^{2}, R^{2}=0.45$.

$\triangle$ Billa Billa: $y=10.75-0.184 x+0.0102 * * x^{2}, R^{2}=0.50$.

Table 7. Ratios of organic $\mathbf{C}$ and total $\mathbf{N}$ initially and at equilibrium ${ }^{\mathrm{A}}$

\begin{tabular}{|c|c|c|c|c|c|c|c|}
\hline \multirow[t]{2}{*}{ Soil series } & \multirow{2}{*}{$\begin{array}{l}\text { Soil depth } \\
\text { (m) }\end{array}$} & \multicolumn{2}{|c|}{$\mathrm{C}: \mathrm{N}$ ratios } & \multirow{2}{*}{ Soil series } & \multirow{2}{*}{$\begin{array}{l}\text { Soil depth } \\
\text { (m) }\end{array}$} & \multicolumn{2}{|c|}{$\mathrm{C}: \mathrm{N}$ ratios } \\
\hline & & Initial & Equilibrium & & & Initial & Equilibrium \\
\hline \multirow[t]{4}{*}{ Waco } & $0-0 \cdot 1$ & $11 \cdot 3$ & $13 \cdot 5$ & \multirow[t]{4}{*}{ Langlands-Logie } & $0-0 \cdot 1$ & $11 \cdot 1$ & $9 \cdot 2$ \\
\hline & $0-0 \cdot 2$ & $11 \cdot 0$ & $13 \cdot 7$ & & $0-0 \cdot 2$ & $11 \cdot 3$ & $10 \cdot 4$ \\
\hline & $0-0 \cdot 3$ & $11 \cdot 2$ & $13 \cdot 5$ & & $0-0 \cdot 3$ & $11 \cdot 1$ & $10 \cdot 3$ \\
\hline & $0-0 \cdot 6$ & $12 \cdot 2$ & $14 \cdot 7$ & & $0-0.6$ & $11 \cdot 4$ & $10 \cdot 9$ \\
\hline
\end{tabular}

${ }^{A}$ From initial and equilibrium values of organic C (Table 4, Dalal and Mayer 1986b, and R. C. Dalal, unpublished data) and total $\mathrm{N}$ (Table 3).

The C:N ratios of Cecilvale, Thallon and Riverview soils showed no significant relationships with the period of cultivation.

\section{Discussion}

\section{Total $N$ Concentration and C:N Ratio of Virgin Soils}

Spain et al. (1983) summarised the total $\mathrm{N}$ concentrations in the top layer $(0-0.1 \mathrm{~m})$ of black earths $(0.08-0 \cdot 21 \%)$ and grey, brown and red clays $(0 \cdot 04-0 \cdot 17 \%)$ in Australia. The total $\mathrm{N}$ concentrations of five of the six soil series in this study (Table 1) were found to be in this range; the exception was the 
Langlands-Logie soil, which was developed under brigalow (Acacia harpophylla) and had a higher $\mathrm{N}$ concentration. Total amounts of $\mathrm{N}$ found in the soil profiles $(0-1 \cdot 2 \mathrm{~m})$ were lower than those found in 61 soils (Oxisols, Mollisols, Alfisols and Ultisols) of the tropical region $\left(9400 \mathrm{~kg} \mathrm{~N} / \mathrm{ha} \mathrm{m}^{-1}\right)$ but similar to that in 45 soils (Mollisols, Alfisols and Ultisols) of the temperate region $\left(7220 \mathrm{~kg} \mathrm{~N} / \mathrm{ha} \mathrm{m}^{-1}\right.$ ) (Sanchez et al. 1982). However, Thallon and Riverview soils contained much less total $\mathrm{N}$, possibly due to a drier moisture regime in this semi-arid, sub-tropical region.

Total $\mathrm{N}$ was significantly correlated with other components of soil organic matter, including organic $\mathrm{C}$, organic $\mathrm{P}$ and $\mathrm{S}$. As for organic $\mathrm{C}$, total $\mathrm{N}$ content also increased with an increase in mean annual rainfall, reflecting the total amount of dry matter produced and returned to the soil. Presumably, soil constituents that protect organic $\mathrm{C}$ and make it inaccessible to microorganisms and degradative enzymes (Dalal and Mayer $1986 b$ ) also protect organic $\mathrm{N}$.

However, the relationship between organic $\mathrm{C}$ and total $\mathrm{N}$ differed among these soils, the $\mathrm{C}: \mathrm{N}$ ratio for $0-0 \cdot 1 \mathrm{~m}$ depth varying from $10 \cdot 6$ to $15 \cdot 2$ (Table 1 ) in virgin soils. It is unlikely that differences in the $\mathrm{C}: \mathrm{N}$ ratio of these soils were due to fixed $\mathrm{NH}_{4}-\mathrm{N}$, as such differences would lead to much lower $\mathrm{C}: \mathrm{N}$ ratios $(<10)$ in deeper layers (Young and Aldag 1982). The significant relationship between dithionite extractable $\mathrm{Fe}$ ('active' $\mathrm{Fe}$ ) and $\mathrm{C}: \mathrm{N}$ ratio suggests the possibility of differential protection provided to organic $\mathrm{C}$, although the effect of native vegetation on $\mathrm{C}: \mathrm{N}$ ratio (Russell 1973) cannot be ruled out.

\section{Kinetics of Total $N$ Loss from Soil}

The rate of loss of total $\mathrm{N}, k_{\mathrm{w}}\left(0 \cdot 06-0 \cdot 27\right.$ year $\left.^{-1}\right)$, obtained for Waco, Langlands-Logie and Cecilvale soils $(0-0.1 \mathrm{~m})$ are within the range of values found in tropical and temperate soils $(k=0.022-0.33$; Hobbs and Thompson 1971; Lathwell and Bouldin 1981; Russell 1981).

The linear decline in total $\mathrm{N}$ from the top layer $(0-0.1 \mathrm{~m})$ with the period of cultivation observed in Billa Billa, Thallon and Riverview soils (Fig. 1) is not frequently noted, although Rasmussen et al. (1980) obtained such changes for a wheat-fallow cropping sequence in a semiarid soil over 45 years of cultivation. One likely explanation is that in lower rainfall areas, nitrogen mineralised from organic matter is not removed in crops as frequently and perhaps as much as in higher rainfall areas, and it either gets immobilised by decomposing crop residues or accumulates as mineral $\mathrm{N}$ in the profile. It is also likely that since Billa Billa, Thallon and Riverview soils have been cultivated over shorter periods (20-25 years v. 35-70 years) than the other three remaining soil series, the curvilinear decline of total $\mathrm{N}$ is not yet significant in the former three soils.

The total $\mathrm{N}$ concentrations likely to occur at equilibrium under the current cultural practices, $0 \cdot 039-0 \cdot 78 \% \mathrm{~N}$ (Table 2), were lower than the value $(0 \cdot 103 \%$ N) calculated for an Argiustoll (Chernozem) (Hobbs and Thompson 1971), but similar to that $(0.05 \% \mathrm{~N})$ for a Vertisol estimated for continuous sorghum cropping (Russell 1981). In India, where Vertisols have been cultivated for hundreds of years, $\mathrm{N}$ concentration varies from $0.028 \%$ to $0.054 \%$, with a mean value of about $0.04 \% \mathrm{~N}$ in the surface layer (Dudal 1965).

The loss of total $\mathrm{N}$ from subsoils ( $>0.1 \mathrm{~m}$ depth) observed in this study has also been found in other soils (Haas et al. 1957; Hobbs and Thompson 1971). 
Generally, the rate of soil $\mathrm{N}$ loss declined with increasing clay content. It is inferred that the clay fraction provided protection to organic matter or made it less accessible to degradative enzymes (Dalal and Mayer 1986b).

\section{Total $N$ in Soil-Plant System}

Annual rate of loss of soil $\mathrm{N}$ from the profiles of five soils can be accounted for by that removed in crops (Tables 5 and 6 ). In Waco soil, $\mathrm{N}$ removal by the crop may have exceeded that lost from $0-1 \cdot 2 \mathrm{~m}$ soil depth. It is likely that $\mathrm{N}$ from deeper layers was used by crops, such as sorghum which is more frequently grown on this soil (Dalal and Mayer 1986a). No such process is likely for Billa Billa soils, because no significant amount of $\mathrm{N}$ was removed below $0.3 \mathrm{~m}$ depth (Table 5). Nitrogen accretion through symbiotic nitrogen fixation was negligible because no leguminous crops were grown, although asymbiotic nitrogen fixers may have contributed some $\mathrm{N}$.

Another possibility is that crop $\mathrm{N}$ removal over the longer term estimated from the 1982-84 period is probably an over-estimate because of the more favourable seasons in recent years, although $\mathrm{N}$ yields are less affected than dry matter or grain yields by unfavourable seasonal conditions. Furthermore, current, higher-yielding cultivars may remove larger quantities of $\mathrm{N}$ than the earlier cultivars.

In the Langlands-Logie soil, any total $\mathrm{N}$ lost in excess of $\mathrm{N}$ removal by the crops could have been due to leaching losses, for Waring and Teakle (1960) found $N$ leached beyond the rooting zone. Significant amount of $\mathrm{NO}_{3}-\mathrm{N}$ found between $1.2 \mathrm{~m}$ and $3.0 \mathrm{~m}$ depths in fields cultivated for up to 10 years could account for the excess $\mathrm{N}$ loss, although after 45 years of cultivation only small amounts of $\mathrm{NO}_{3}-\mathrm{N}$ were found in this zone ( $\mathrm{R}$. C. Dalal, unpublished data).

Similar studies done elsewhere on soils subjected to long periods of cultivation have shown that in most cases soil $\mathrm{N}$ losses were primarily accounted for by $\mathrm{N}$ removal by crops (Haas et al. 1957; Williams and Lipsett 1961; Clarke and Russell 1977), especially where no organic manures or fertilisers have been added (Russell 1973). Admittedly large errors are likely to occur in such studies. Ladd and Russell (1983) summarised the results of a number of glasshouse and lysimeter experiments on recovery of applied ${ }^{15} \mathrm{~N}$. They found that recovery exceeded $90 \%$ in the soil-plant system. In field experiments, however, the recoveries of ${ }^{15} \mathrm{~N}$ varied from $29 \%$ to $98 \%$. Besides leaching losses, denitrification and ammonia volatilisation may also have been involved.

The continual depletion of $\mathrm{N}$, albeit mostly removed by crops, accompanied by decreasing crop yields (Dalal and Mayer 1986a), is a cause for concern for stable crop production on these soils. Already economic crop yields are not possible on long-term ( $>30$ years) cultivated Waco and Cecilvale soils on the Darling Downs without the addition of nitrogen ( $\mathrm{P}$. Wylie, personal communication). Similar situations will be likely to occur on other soils in the not too distant future, especially under optimum moisture conditions. It is imperative for sustainable crop production in this region to find out the appropriate cropping and management systems which would restore or maintain the fertility of these soils, because in drier areas and those of unreliable rainfall, economic returns from application of $\mathrm{N}$ fertilizers are uncertain. Furthermore, higher unaccounted for $\mathrm{N}$ losses may occur from fertilizer $\mathrm{N}$ than from soil $\mathrm{N}$ (Russell 1973). 


\section{Relationship between C: $N$ Ratio and Period of Cultivation}

Haas et al. (1957) reported that $C: N$ ratios were lower in cultivated than virgin soil, that is, the loss of organic $\mathrm{C}$ exceeded that of total $\mathrm{N}$. Similar results were obtained by Hobbs and Thompson (1971). Although the results from Langlands-Logie soil generally agree with these observations, the Waco soil behaved otherwise (Fig. 3 and Table 7). Campbell (1978) obtained conflicting trends in $\mathrm{C}: \mathrm{N}$ ratios in different soils.

Within a soil group, however, $\mathrm{C}: \mathrm{N}$ ratio provides an indication of $\mathrm{N}$ mineralisation and immobilisation in the soil (Campbell 1978). In Waco soil, therefore, increase in $\mathrm{C}: \mathrm{N}$ ratio with period of cultivation indicates that the remaining organic matter would mineralise $\mathrm{N}$ less readily than before. Thus, the fertility loss (rate of $\mathrm{N}$ mineralization) may be disproportionately greater than that shown by the decrease in total soil $\mathrm{N}$. This would result in an increasing fertiliser $\mathrm{N}$ requirement by the crop with increasing period of cultivation. Since organic matter in different particle-size fractions and light fractions $\left(<2 \mathrm{M} \mathrm{g} \mathrm{m}^{-3}\right)$ is lost at different rates (Dalal and Mayer 1986c, 1986d), the C:N ratio of $\mathrm{N}$ of these individual fractions should provide a better indication of organic matter mineralization (lability) than that based on the whole soil. The results from such a study will be reported subsequently.

\section{Acknowledgments}

The authors are grateful to Mrs. A. Pumfrey for total N analyses of soils and Drs A. L. Clarke and W. M. Strong for valuable suggestions.

\section{References}

Black, A. S., and Waring, S. A. (1972). Ammonium fixation and availability in some cereal producing soils in Queensland. Aust. J. Soil Res. 10, 197-207.

Campbell, C. A. (1978). Soil organic C, nitrogen and fertility. In 'Soil Organic Matter'. (Eds M. Schnitzer and S. U. Khan.) pp. 173-271. (Elsevier: New York.)

Clarke, A. L., and Russell, J. S. (1977). Crop sequential practices. In 'Soil Factors in Crop Production in a Semi-Arid Environment'. (Eds J. S. Russell and E. L. Greacen.) pp. 293-5. (University of Queensland Press: St. Lucia, Qld.)

Clarke, G. B., and Marshall, T. J. (1947). Influence of cultivation on soil structure and its assessment in soils of variable mechanical composition. J. Counc. Sci. Ind. Res. Aust. 20, 162-75.

Dalal, R. C., and Mayer, R. J. (1986a). Long-term trends in fertility of soils under continuous cultivation and cereal cropping in Southern Queensland. I. Overall changes in soil properties and trends in winter cereal yields. Aust. J. Soil. Res. 24, 265-79.

Dalal, R. C., and Mayer, R. J. (1986b). Long-term trends in fertility of soils under continuous cultivation and cereal cropping in Southern Queensland. II. Total organic carbon and its rate of loss from the soil profile. Aust. J. Soil Res. 24, 281-92.

Dalal, R. C., and Mayer, R. J. (1986c). Long-term trends in fertility of soils under continuous cultivation and cereal cropping in Southern Queensland. III. Distribution and kinetics of soil organic carbon in particle-size fractions. Aust. J. Soil Res. 24, 293-300.

Dalal, R. C., and Mayer, R. J. (1986d). Long-term trends in fertility of soils under continuous cultivation and cereal cropping in Southern Queensland. IV. Loss of organic carbon from different density fractions. Aust. J. Soil Res. 24, 301-9.

Dalal, R. C., Sahrawat, K. L., and Myers, R. J. K. (1984). Inclusion of nitrate and nitrite in the Kjeldahl nitrogen determination of soils and plant materials using sodium thiosulphate. Commun. Soil Sci. Plant Anal. 15, 1453-61.

Draper, N. R., and Smith, H. (1966). 'Applied Regression Analysis.' (John Wiley \& Sons: New York.) Dudal, R. (1965). 'Dark Clay Soils of Tropical and Sub-tropical Regions.' (F.A.O.: Paris.) 
Haas, H. J., Evans, C. E., and Miles, E. F. (1957). Nitrogen and carbon changes in Great Plains soils as influenced by cropping and soil treatments. Tech. Bull. U.S. Dep. Agric. Washington. No. 1164.

Hobbs, J. A., and Thompson, C. A. (1971). Effect of cultivation on the nitrogen and organic carbon contents of a Kansas Arguistoll (Chernozem). Agron. J, 63, 66-8.

Jenkinson, D. S. (1966). The turnover of organic matter in soil. In 'The Use of Isotopes in Soil Oganic Matter Studies'. Report FAO/IAEA Tech. Meeting, Brunswick-Volkenrode, 1963. pp. 187-97. (Pergamon: London.)

Ladd, J. N., and Russell, J. S. (1983). Soil nitrogen. In 'Soils: an Australian Viewpoint'. (Ed. Division of Soils, CSIRO.) pp. 589-607. (CSIRO Aust.: Melbourne.)

Lathwell, D. J., and Bouldin, D. R. (1981). Soil organic matter and soil nitrogen behaviour in cropped soils. Trop. Agric. (Trinidad) 58, 341-8.

Martin, A. E., and Cox, J. E. (1956). Nitrogen studies on black soils from Darling Downs, Queensland. 1. Seasonal variations in moisture and mineral nitrogen fractions. Aust. J. Agric. Res. 7, 169-83.

Rasmussen, P. E., Allmaras, R. R., Rohde, R. C., and Roager, Jr, N. C. (1980). Crop residue influences on soil carbon and nitrogen in a wheat-fallow system. Soil Sci. Soc. Am. J. 44, 596-600.

Russell, E. W. (1973). 'Soil Conditions and Plant Growth.' (Longmans: London.)

Russell, J. S. (1981). Models of long term soil organic nitrogen change. In 'Simulation of Nitrogen Behaviour of Soil-Plant Systems'. (Eds M. J. Frissel and J. A. van Veen.) pp. 222-32. (Centre for Agricultural Publishing and Documentation: Wageningen.)

Sanchez, P. A., Gichuru, M. P., and Katz, L. B. (1982). Organic matter in major soils of the tropical and temperate regions. Trans. 12th Int. Congr. Soil Sci. Vol. 2, pp. 99-114.

Spain, A. V., Isbell, R. F., and Probert, M. E. (1983). Soil organic matter. In 'Soils: an Australian Viewpoint'. (Ed. Division of Soils, CSIRO.) pp. 551-64. (CSIRO Aust.: Melbourne.)

Waring, S. A., and Teakle, L. J. H. (1960). Fertility investigations on the black earth wheatlands of the Darling Downs, Queensland. III. Mineral nitrogen in the soil and its relation to the wheat crop. Aust. J. Agric. Res. 11, 27-41.

Williams, C. H., and Lipsett, J. (1961). Fertility changes in soils cultivated for wheat in southern New South Wales. Aust. J. Agric. Res. 12, 612-20.

Young, J. L., and Aldag, R. W. (1982). Inorganic forms of nitrogen in soils. In 'Nitrogen in Agricultural Soils'. (Ed. F. J. Stevenson.) pp. 43-6. (American Society of Agronomy: Madison, Wisc.). 